\title{
A new range-extending record of the invasive sea squirt Styela clava in the north of Scotland
}

\author{
Andrew Want ${ }^{1 *}$ and Jenni E. Kakkonen ${ }^{2}$
}

\begin{abstract}
A new record of an individual of the invasive sea squirt, Styela clava, is reported from Scapa Flow in Orkney, Scotland. This represents a $1.54^{\circ}$ latitudinal extension $(168 \mathrm{~km})$ from the previous northern-most record in UK waters. Diver surveys of hard substrates in the immediate area, part of local biosecurity protocols, did not find any additional individuals. Possible transport vectors, likelihood of an established reproductively active population, and implications to local biodiversity are discussed.
\end{abstract}

Keywords: Styela clava, Sea squirt, Tunicate, Invasive species, British waters

\section{Introduction}

The leathery or clubbed sea squirt Styela clava Herdman (1881) is a solitary ascidian tunicate with a distinct long tapering body and stalk (Lützen 1998; Clarke and Therriault 2007). S. clava is found from low intertidal zones to subtidal depths of up to $40 \mathrm{~m}$ and grows on artificial and natural hard substrates (Lützen 1998; Clarke and Therriault 2007). This species can survive a wide range of temperatures, from 2 to $23^{\circ} \mathrm{C}$ (Clarke and Therriault 2007), but appears to be intolerant of low salinity (below 20\%) (Davis and Davis 2008). Adults range in size from approximately $90-160 \mathrm{~mm}$ in length (Lützen 1998).

Styela clava is native to the northwest Pacific Ocean, from the Sea of Okhotsk to Shanghai, China (NBN 2021a) but has aggressively spread through temperate waters around the globe (Lützen 1998; Clarke and Therriault 2007; Goldstien et al. 2011). The first occurrence outside of its native range was recorded in California in 1933 (Abbott and Johnson 1972). In 1953, S. clava was found in English waters in the Plymouth area (Carlisle 1954) and has since spread extensively through the northeast

\footnotetext{
* Correspondence: a.want@hw.ac.uk

${ }^{1}$ International Centre for Island Technology, Heriot Watt University, Orkney

Campus, Stromness, UK

Full list of author information is available at the end of the article
}

Atlantic from Denmark to Portugal, and into the Mediterranean Sea (Davis and Davis 2008). In British and Irish waters, S. clava has been rapidly spreading northwards into Scotland (Eno et al. 1997; Lützen 1998) and westwards from Dublin Bay to Co. Kerry in Ireland (Minchin et al. 2006).

S. clava is considered to be an invasive nonindigenous species owing to its tendency to replace native species with the consequence of reduced local biodiversity, and for the potential economic impacts in areas where it has become established (Clarke and Therriault 2007). S. clava is one of the High-Risk Invasive Species highlighted in the approved Orkney Islands Council Harbour Authority's Ballast Water Management Policy for Scapa Flow (OIC BWMP) (Orkney Islands Council Harbour Authority 2017). Under this policy, a dedicated marine non-native species (NNS) monitoring programme has been on-going since 2013 and has not recorded S. clava to date (Kakkonen et al. 2019). In 2010, the most northerly UK record of this species was documented at Ardnaff on the shores of Loch Carron in Wester Ross (57.36388 N; 5.5128 W) (NBN 2021a).

(c) The Author(s). 2021, corrected publication 2021. Open Access This article is licensed under a Creative Commons Attribution 4.0 International License, which permits use, sharing, adaptation, distribution and reproduction in any medium or format, as long as you give appropriate credit to the original author(s) and the source, provide a link to the Creative Commons licence, and indicate if changes were made. The images or other third party material in this article are included in the article's Creative Commons licence, unless indicated otherwise in a credit line to the material. If material is not included in the article's Creative Commons licence and your intended use is not permitted by statutory regulation or exceeds the permitted use, you will need to obtain permission directly from the copyright holder. To view a copy of this licence, visit http://creativecommons.org/ licenses/by/4.0/. 


\section{Materials and methods}

In July 2018, as part of the BioFREE project, monitoring biofouling and testing antifouling coatings (Want et al. 2021), settlement panels were deployed at several locations in Orkney, Scotland. Panels were fitted to a frame comprised primarily of marine grade stainless steel and high-density polypropylene. One of these test sites was located in Scapa Flow (58.901449 N; 2.939823 W), approximately $0.71 \mathrm{~km}$ from the nearest shore and $7.14 \mathrm{~km}$ from the nearest port. At this site, frames were suspended $3 \mathrm{~m}$ above the seabed in $24 \mathrm{~m}$ of water depth. On 18 December 2020, following a schedule of periodic retrievals (most recently on 21 September 2019), monitoring and testing frames at Scapa Flow were recovered, and images and samples were collected, before redeployment. Samples were taken to the laboratory at Heriot Watt University in Stromness for identification and preservation in $70 \%$ ethanol.

As a consequence of the BioFREE survey, a dedicated two-phase survey was performed for the presence of $S$. clava at the Scapa Flow test site. In Phase 1, on 11 February 2021, a side-scan sonar survey was conducted of the seabed (approx. Area of $0.5 \mathrm{~km} \times 1 \mathrm{~km}$ ) adjacent to the settlement panels. A CM2 standard towfish and transceiver unit (C-MAX) was used on high frequency setting $(780 \mathrm{kHz})$ to locate hard objects within the site boundaries which might provide suitable settlement substrate for S. clava. In Phase 2, on 17-18 March 2021, diver-based surveys of six targets were conducted in 'buddy' pairs with one diver conducting video survey while second diver was prepared to collect samples of $S$. clava.

\section{Results}

Settlement panels and the surrounding frame components deployed in Scapa Flow were heavily fouled, primarily by the sea squirt Ascidiella aspersa. Other key fouling species included the sea anemone Metridium dianthus and the sea squirt Ciona intestinalis. Amid the dominant fouling organisms was a single distinctlooking individual tunicate attached to one of the steel frame components by a long tough stalk (Fig. 1). Taxonomic guides (Hayward and Ryland 2017; Bowen et al. 2018) were used to identify this organism as S. clava; verification was provided by the National Biodiversity Network (NBN 2021b). This individual measured approximately $100 \mathrm{~mm}$ long, indicative of an adult (Fig. 2).

Phase 1 side-scan surveys identified eight large targets, two of which deemed unsuitable for the Phase 2 dive surveys. Five concrete mooring blocks and a debris site surveyed by diving in Phase 2 had varied fouling cover from heavily fouled to almost bare. Key fouling species observed were sea squirts $C$. intestinalis, A. aspersa, Ascidia mentula, Devonshire cup coral Caryophillia smithii, sea anemone $M$. dianthus, encrusting worms Spirobranchus and Spirorbis spp. and hydrozoans. The diver-based surveys did not record any S. clava.

\section{Discussion}

The invasive non-indigenous leathery sea squirt S. clava has been rapidly expanding its range in UK waters since being first recorded in the early 1950s. This new report from Scapa Flow in Orkney of a single adult specimen constitutes a $1.54^{\circ}$ latitudinal extension from the previously recognised most northerly record, from Loch

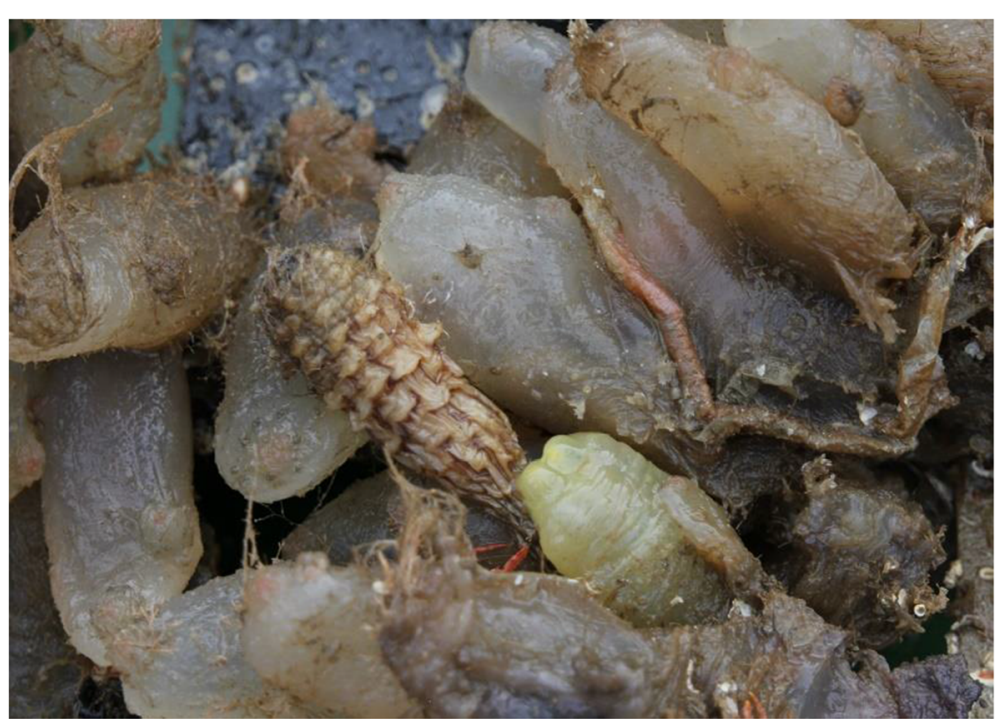

Fig. 1 Detail of fouling organisms retrieved from Scapa Flow on 18 December 2020. Fouling was dominated by the solitary tunicate Ascidiella aspersa but included a single individual of the leathery sea squirt Styela clava. This image also features an individual Ciona intestinalis sea squirt 


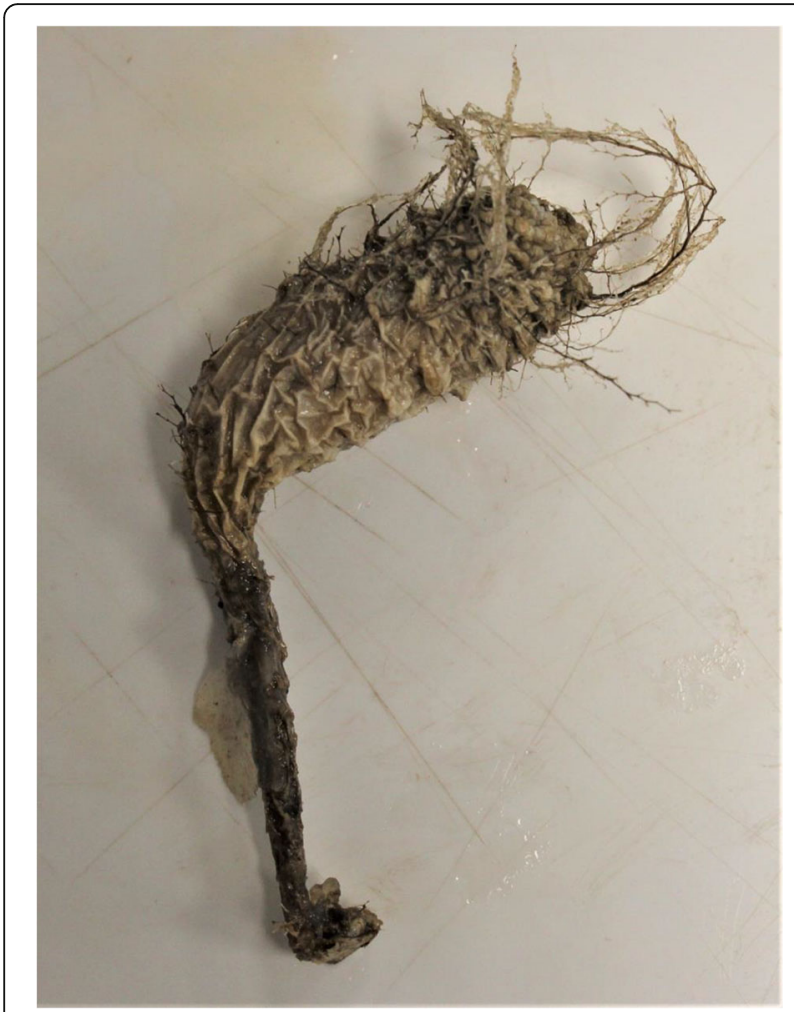

Fig. 2 Image of the single Styela clava specimen collected in Scapa Flow, Orkney on 18 December 2020 (approximately 100 mm length)

Carron. This represents a poleward shift of the known distribution limit of S. clava of $168 \mathrm{~km}$ (Fig. 3). Subsequent diver-based surveys of suitable substrates for recruitment of this species in the immediate area did not find any additional examples. The possibility of establishment of S. clava in Orkney and the potential ecological impacts of its presence are of great concern from a local biodiversity perspective and may impact aquaculture installations (Davis and Davis 2008; Darbyson et al. 2009).

Recruitment of S. clava extends from June to lateOctober (Bourque et al. 2007) and adult size is typically reached by 10 months (Lützen 1998). This suggests that the Orkney individual had settled on to the monitoring frame in 2019, as earlier sampling surveys had not detected its presence. While S. clava appears to tolerate a wide range of temperatures, evidence indicates that a lower limit of $15^{\circ} \mathrm{C}$ is necessary for spawning (Bourque et al. 2007). As such, colder waters in Orkney, where mean monthly sea surface temperatures peak at about $13.5^{\circ} \mathrm{C}$, may prevent establishment of self-sustaining populations of $S$. clava. The single record reported here and absence in subsequent surveys suggest that the presence of $S$. clava in Orkney waters may be limited to introduction by fouling vectors without establishing a breeding population.
Concerns exist over the role that increasing sea temperatures associated with climatic change may help expand the potential range of $S$. clava into waters which may have formerly been too cold for population establishment. Sea surface temperature monitoring at Kirkwall Marina in Orkney began in 2015 (Kakkonen et al. 2019). In the last 4 years (2017-2020), summer sea surface temperatures have reached $15^{\circ} \mathrm{C}$ for between 7 and 15 consecutive days (OICHA, unpublished data). This micro-climate and the presence of suitable vectors for invasive NNS may create conditions allowing the establishment of a viable $S$. clava population.

The larvae of S. clava spend only a short period in the planktonic phase (Stachowicz et al. 2002). Given the considerable distance between known populations of $S$. clava and Orkney, and the presence of a hydrographic barrier created by the fierce tidal currents flowing through the wide Pentland Firth, it is unlikely that $S$. clava has reached Orkney through larval dispersal, although natural transport while attached to drifting seaweed, e.g. Sargassum, cannot be ruled out (Lützen 1998). In UK waters, patchy distribution of S. clava and its absence from apparently suitable adjacent locations suggests that patterns of vector traffic may be a better predictor of its potential spread than local habitat characteristics (Clarke and Therriault 2007; Davis and Davis 2008).

Primary introduction into UK waters is believed to have occurred on the hulls of naval vessels returning from the Korean War (Eno et al. 1997). Once established, artificial structures facilitate $S$. clava spread to new areas by acting as 'stepping-stones', and reintroduction is possible via hull fouling and ballast water (Eno et al. 1997; Lützen 1998; Clarke and Therriault 2007; Davis and Davis 2008; Darbyson et al. 2009). The presence of S. clava in harbours and marinas in close proximity to oyster farming, and its absence from locations without shellfish aquaculture, suggests that the spread of S. clava may be linked to the transfer of oysters between facilities (Davis and Davis 2008; Darbyson et al. 2009). There are currently two oyster farms and one hatchery operating in Orkney waters. A variety of vessels could provide a substrate for transmission, including small recreational craft (Minchin et al. 2006; Darbyson et al. 2009). At ports with established populations of S. clava, larvae may settle and grow on vessel hulls. While hydrodynamic forces experienced during vessel travel may prevent survival on the external hull, the presence of socalled 'niche' areas including sea-chests, thruster tubes, and other cavities, may provide places for fouling species to persist (Coutts and Taylor 2004; Davis and Davis 2008). Transfer of $S$. clava through ballast water is deemed unlikely owing to the short larval period of this species (Clarke and Therriault 2007). 


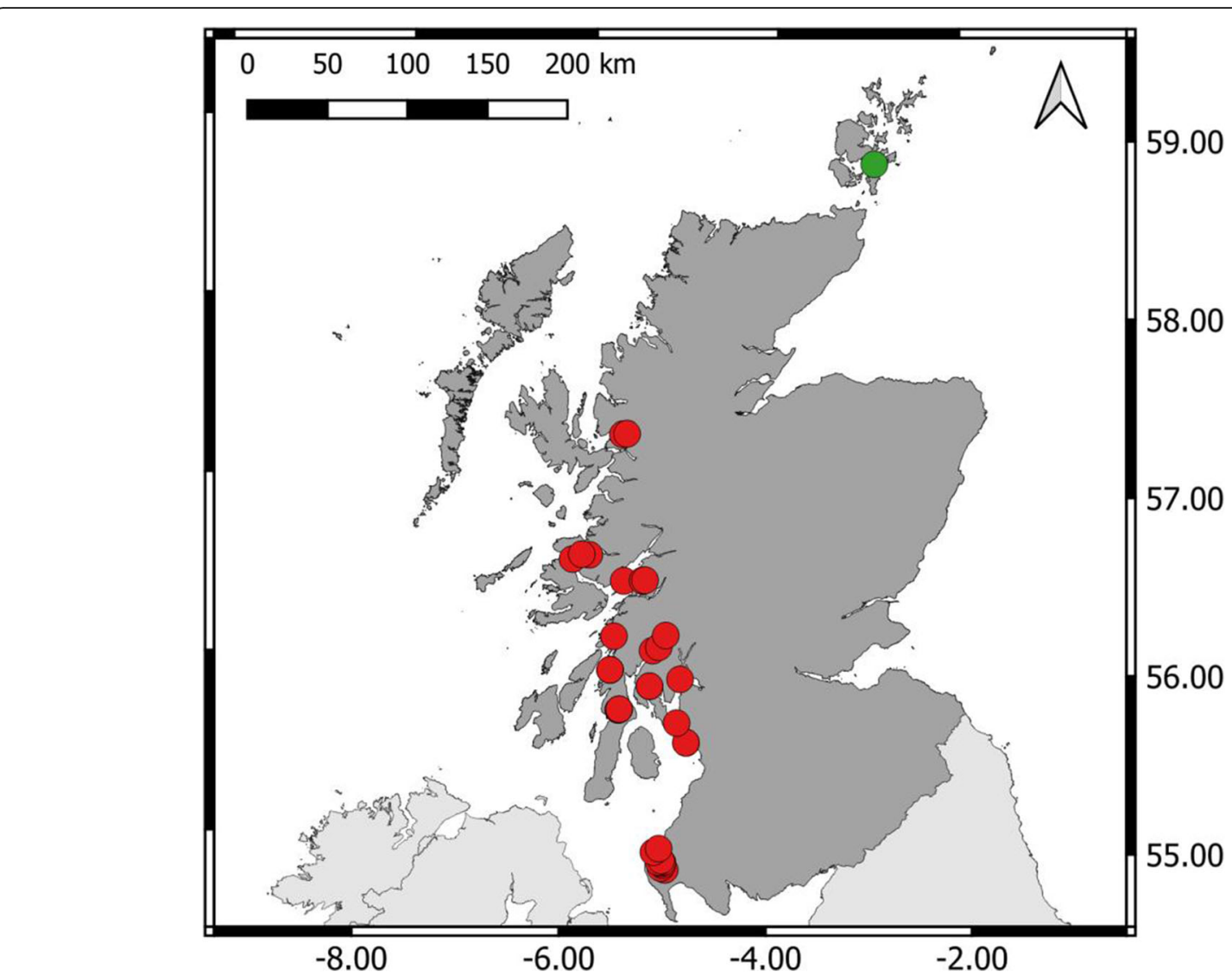

Fig. 3 Map of Scotland indicating the location of the new range-extending specimen of Styela clava in Scapa Flow, Orkney (58.901449 N; $2.939823 \mathrm{~W}$ ) in green and previous recorded locations in Scotland indicated in red, including the former northern-most record in the UK in Loch Carron, Wester Ross ( 57.36388 N; 5.5128 W). Previous location records provided by the National Biodiversity Network (NBN 2021a)

\section{Conclusion}

The spread of invasive NNS, such as S. clava, is a serious concern to local ecosystems and economies; eradication programmes are costly and may not be fully successful (Sambrook et al. 2014). S. clava can reach densities of up to 1500 individuals per square meter (Cohen 2011), reducing available space resource for native epibenthic organisms. Filtration pressure from untreated S. clava invasions may further impact local ecology by depleting plankton stock (Sonier et al. 2018), and may impact aquaculture where mussel productivity may be decreased by up to $40 \%$ (Davis and Davis 2008).

Biosecurity-orientated surveys and on-going monitoring of NNS hotspots are necessary to determine the spread of invasive marine species. On-going long-term monitoring and reactive sampling and surveys, as described in this study, are vital for early detection of invasive NNS and for rapid management action plan (Sambrook et al. 2014). The use of settlement panels and diver surveys have been shown to be an effective method of detecting marine invasive species, including S. clava (Gust et al. 2008; Marraffini et al. 2017; Wood et al. 2019). Detecting the presence of invasive species may be enhanced through molecular techniques, such as real-time PCR analysis (Wood et al. 2019). Phylogeographic analysis may be used to help identify source populations (Goldstien et al. 2011) necessary to establish routes and potential transport vectors.

\section{Acknowledgments}

the authors wish to express their gratitude to Chris Page for GIS assistance, Leask Marine, the European Marine Energy Centre for boat-work and access to their Scapa Flow test site, and SULA Diving for their assistance in planning and completing the side scan and dive surveys. The authors thank the anonymous reviewers for their valuable comments on our manuscript.

\section{Authors' contributions}

AW (Principal Investigator) performed the initial field work, identified the sample, and provided most of the text for this manuscript. JK organised and led subsequent survey work and made a major contribution to the methods and discussion of the manuscript. Both authors read, revised, and approved the final manuscript.

\section{Funding}

BioFREE monitoring and testing equipment was supported by a Natural Environment Research Council funded Innovation Placement: NE/R006954/1; subsequent side scan and dive surveys were funded by Orkney Islands Council Harbour Authority.

\section{Availability of data and materials}

The collected sample was deposited at the Orkney campus of Heriot Watt University and is available upon request. 


\section{Declarations}

Ethics approval and consent to participate

Not applicable.

\section{Consent for publication}

Not applicable.

\section{Competing interests}

The authors declare that they have no competing interests.

\section{Author details}

${ }^{1}$ International Centre for Island Technology, Heriot Watt University, Orkney Campus, Stromness, UK. '2Orkney Harbour Authority, Orkney Islands Council, Scapa, Orkney, UK.

Received: 11 May 2021 Accepted: 9 August 2021

Published online: 19 August 2021

\section{References}

Abbott DP, Johnson JV. The ascidians Styela barnharti, S. plicata, S. clava, and S. montereyensis in Californian waters. Bull South Calif Acad Sci. 1972;71:95-105.

Bourque D, Davidson J, MacNair NG, Arsenault G, LeBlanc AR, Landry T, et al. Reproduction and early life history of an invasive ascidian Styela clava Herdman in Prince Edward Island, Canada. J Exp Mar Biol Ecol. 2007;342(1): 78-84.

Bowen S, Goodwin C, Kipling D, Picton BE. Sea Squirts and Sea Sponges of Britain and Ireland. Plymouth: Princeton University Press; 2018.

Carlisle DB. Styela mammiculata n. sp., a new species of ascidian from the Plymouth area. J Mar Biol Assoc U K. 1954;33(2):329-34. https://doi.org/10.101 7/S0025315400008365.

Clarke CL, Therriault TW. Biological synopsis of the invasive tunicate Styela clava (Herdman 1881): Fisheries and Oceans Canada, Science Branch, Pacific Region. Nanaimo: Pacific Biological Station; 2007.

Cohen AN. The exotics quide: non-native marine species of the North American Pacific Coast. Richmond; Oakland: Center for Research on Aquatic Bioinvasions and San Francisco Estuary Institute; 2011.

Coutts ADM, Taylor MD. A preliminary investigation of biosecurity risks associated with biofouling on merchant vessels in New Zealand. New Zeal J Mar Fresh. 2004;38(2):215-29. https://doi.org/10.1080/00288330.2004.9517232.

Darbyson EA, Hanson JM, Locke A, Willison JM. Settlement and potential for transport of clubbed tunicate (Styela clava) on boat hulls. Aquat Invasions. 2009;4(1):95-103. https://doi.org/10.3391/ai.2009.4.1.10.

Davis MH, Davis ME. First record of Styela clava (Tunicata, Ascidiacea) in the Mediterranean region. Aquat Invasions. 2008;3(2):125-32. https://doi.org/1 0.3391/ai.2008.3.2.2.

Eno NC, Clark RA, Sanderson WG. Non-native marine species in British waters: a review and directory. Peterborough: Joint Nature Conservation Committee; 1997. p. 133-4.

Goldstien SJ, Dupont L, Viard F, Hallas PJ, Nishikawa T, Schiel DR, et al. Global phylogeography of the widely introduced North West Pacific ascidian Styela clava. PLoS One. 2011;6(2):e16755

Gust N, Inglis G, Floerl O, Peacock L, Denny C, Forrest B. Assessment of population management options for Styela clava. MPI Technical paper. 2008; No: 2009/04.

Hayward PJ, Ryland JS. Handbook of the marine fauna of North-West Europe. Oxford: Oxford University Press; 2017.

Kakkonen JE, Worsfold TM, Ashelby CW, Taylor A, Beaton K. The value of regular monitoring and diverse sampling techniques to assess aquatic non-native species: a case study from Orkney. Manag Biol Invasions. 2019;10(1):46-79. https://doi.org/10.3391/mbi.2019.10.1.04.

Lützen J. Styela clava Herdman (Urochordata, Ascidiacea), a successful immigrant to North West Europe: ecology, propagation and chronology of spread. Helgoländer Meeresuntersuchungen. 1998;52(3):383-91. https://doi.org/10.1 007/BF02908912.

Marraffini ML, Ashton GV, Brown CW, Chang AL, Ruiz GM. Settlement plates as monitoring devices for non-indigenous species in marine fouling communities. Manag Biol Invasions. 2017:8(4):559-66. https://doi.org/10.3391/ mbi.2017.8.4.11.
Minchin D, Davis MH, Davis ME. Spread of the Asian tunicate Styela clava Herdman, 1882 to the east and south-west coasts of Ireland. Aquat Invasions. 2006;1 (2):91-6. https://doi.org/10.3391/ai.2006.1.2.7.

NBN. Styela clava Herdman, 1881: National Biodiversity Network; 2021a. https:// scotland-species.nbnatlas.org/species/NBNSYS0000178204\#overview. Accessed 21 Apr 2021

NBN. Human observation of Styela clava Herdman, 1881. 2021b. https://records. nbnatlas.org/occurrences/656a4097-8a3a-4bb0-932a-325e2365df42. Accessed 21 Apr 2021.

Orkney Islands Council Harbour Authority. Ballast Water Management Policy for Scapa Flow. 2017. https://www.orkneyharbours.com/site/assets/files/1123/ba llast_water_management_policy_for_scapa_flow_29_november_2017.pdf. Accessed 21 Apr 2021.

Sambrook K, Holt RH, Sharp R, Griffith K, Roche RC, Newstead RG, et al. Capacity, capability and cross-border challenges associated with marine eradication programmes in Europe: the attempted eradication of an invasive non-native ascidian, Didemnum vexillum in Wales, United Kingdom. Mar Policy. 2014; 1(48):51-8

Sonier R, Filgueira R, Daoud D, Comeau LA. Feeding pressure of Mytilus edulis and Styela clava on phytoplankton and zooplankton, including lobster larvae (stages I and IV): Fisheries and Oceans Canada. Moncton: Gulf Fisheries Centre; 2018.

Stachowicz JJ, Fried H, Osman RW, Whitlatch RB. Biodiversity, invasion resistance and marine ecosystem function: reconciling pattern and process. Ecology. 2002;83(9):2575-90. https://doi.org/10.1890/0012-9658(2002)083[2575:BIRA ME]2.0.CO:2.

Want A, Harris RE, Hull MQ, Long CR, Porter JS. Sea-trial verification of a novel system for monitoring biofouling and testing anti-fouling coatings in highly energetic environments targeted by the marine renewable energy industry. Biofouling. 2021;37(4):433-51. https://doi.org/10.1080/08927014.2021.1928091.

Wood SA, Pochon X, Ming W, von Ammon U, Woods C, Carter M, et al. Considerations for incorporating real-time $P C R$ assays into routine marine biosecurity surveillance programmes: a case study targeting the Mediterranean fanworm (Sabella spallanzanii) and club tunicate (Styela clava). Genome. 2019;62(3):137-46. https://doi.org/10.1139/gen-2018-0021.

\section{Publisher's Note}

Springer Nature remains neutral with regard to jurisdictional claims in published maps and institutional affiliations.
Ready to submit your research? Choose BMC and benefit from:

- fast, convenient online submission

- thorough peer review by experienced researchers in your field

- rapid publication on acceptance

- support for research data, including large and complex data types

- gold Open Access which fosters wider collaboration and increased citations

- maximum visibility for your research: over $100 \mathrm{M}$ website views per year

At $\mathrm{BMC}$, research is always in progress.

Learn more biomedcentral.com/submissions 